\title{
Slavery in New Jersey: A Roundtable
}

Emily Blanck

Abstract: Slavery in New Jersey offers scholars a rich, untapped source for new scholarship about the meaning of freedom and liberty from the Founding Era to the Civil War. Kean University recently sponsored a panel discussion featuring three scholars and their research into the story of slavery in the Garden State. This opening essay offers a summation of the Kean panel's findings, and offers encouragement to other scholars of slavery in the state.

In the past decade or so, scholarship on slavery has emphasized Northern slavery. This scholarship serves as a reminder to historians and the public that slavery was not a Southern institution; it was an American institution. Much of this emphasis has focused on the American Revolution and its aftermath. This obviously was a crucial moment in the nation's history, because black slavery and freedom sat in the balance as Americans won political independence and then established a republic based on individual liberty. The contradictions, struggles, and victories over slavery and freedom in this milieu make for exciting history. For this precise reason, it is a mystery why historians have largely neglected the history of slavery in New Jersey. Of course, New Jersey has been ignored in favor of its two large neighbors, New York and Pennsylvania, in other areas of history, too. Historians of the 
Revolution, labor, immigration, and urbanization have all also lamented the neglect of New Jersey in their histories.

After reviewing the three works in this collection, it is clear that New Jersey was the perfect battleground for this conflict. The works of Sue Kozel, Timothy Hack, and Jonathan Mercantini demonstrate that New Jersey was becoming both a freer state and a stronger slave state during and after the American Revolution. This paradox reflects the equally paradoxical situation of New Jersey as a state with strong internal division (between East and West Jersey), a significant Quaker population, and with very porous borders with both Southern and Northern states. The internal divisions, existence of Quakers, and weak borders give the history of slavery in New Jersey its own feel. It would not be surprising if future research will show that those porous borders expand throughout the Atlantic world. As these essays demonstrate, this paradoxical state provides an exciting location in which to study America's struggle to become a nation of freedom and slavery.

New Jersey's agriculture, culture, and population have influenced the nature of the slavery in the state. Overall, slaves made up a small but significant part of the population, between 6 and 8 percent overall, a percentage similar to the nearby states of Pennsylvania and New York. 
But if we narrow our focus to the primary slave-owning regions of the state, the percentage rises to close to 10 percent.

The slave-owning regions were primarily in West Jersey, and slavery there had an interesting tenor. As it was for New York and Pennsylvania, New Jersey's bread-basket agriculture created the context for the presence of slavery. The crops required intense seasonal work that needed hands more than muscle. The diminished need for labor off-season meant that having large slave plantations could be financially onerous. Off-season wheat storage, milling, and shipping certainly needed hands but fewer than during the peak season. The seasonal intensity did necessitate a large workforce, and slavery was, therefore, a significant part of the labor economy of the region. In this area, therefore, plantations generally maintained a ratio of 1 to 5 slaves per owner. Since the work required less muscle power, women could prove to be versatile labor, working in the household during off-times and in the fields when necessary. Moreover, larger plantation owners could hire their surplus labor throughout the year for a tidy profit. However, 
the labor market could not reserve too many large plantations with slaves to hire. ${ }^{1}$

Slave-owning ideology combined with the nature of breadbasket slavery to add to the life experiences of slaves in the area. Paternalism, a slave- owning ideology ordinarily associated with the Antebellum South, seems to have governed slavery in New Jersey, and there are some similarities. An active abolitionist movement challenged the slave owners of the Antebellum South, requiring slave owners to adopt slaveowning ideas that recognized slaves' humanity to justify the morality of their actions. The New Jersey region had an early morality-driven and active abolitionist movement led by the large Quaker population in West Jersey. Jonathan Mercantini's examination of John Kean's slaveholding demonstrates this proclivity to paternalistic thought. Likewise, this paternalistic attitude resulted in widespread family formation, as Tim Hack demonstrates, despite the relatively small size of the plantations.

The state of scholarship on New Jersey slavery is extremely thin, despite its interesting textures. Therefore, Professor Hack's work

\footnotetext{
${ }^{1}$ Ira Berlin, Many Thousands Gone: The First Two Centuries of Slavery in North America, (Cambridge, MA: Belknap Press, Harvard University Press, 1998), 134-135, 186; Vivienne Kruger, "Born to Run: The Slave Family in Early New York, 1626-1827," unpublished doctoral dissertation, Columbia University, 1985.
} 
provides some essential basic building blocks of New Jersey slave society. His ability to track the basic demographic and economic circumstances in New Jersey covers scholarship that would have been well-established a couple of generations ago in the Southern states and well-studied today in Northern states like Pennsylvania and Massachusetts. Interestingly, New Jersey’s strong Quaker influence mirrored Pennsylvania, but New Jersey took much longer to end slavery. Clearer understandings of New Jersey slavery would not only advance our knowledge of New Jersey, but also of Pennsylvania. As we understand the New Jersey's Quaker and slave-owning population, we will understand its particular character in Pennsylvania by comparison. The work of Graham Hodges provides an outstanding exception to the silence of slavery scholarship, but it still remains a small drop in a large bucket. ${ }^{2}$ I hope these studies build a foundation to help other scholars feel confident enough to explore New Jersey and advance its slavery scholarship to the depth of these other prominent Northern states.

\footnotetext{
2 See Graham Hodges, Slavery and Freedom in the Rural North: African Americans in Monmouth County, New Jersey (Madison House, 1997), Root and Branch: African Americans in New York and East Jersey, 1613-1863 (University of North Carolina Press, 1999), and "Pretends to be Free": Fugitive Slave Advertisements from Colonial and Revolutionary New York and New Jersey (Garland Publishing Company, 1994)
} 
An understanding of New Jersey's slave system would not be complete without a complete understanding of New Jersey Quakers. Of course, the most radical $18^{\text {th }}$ Century abolitionist, John Woolman, hailed from Mount Holly. But men like Richard Waln, whom Professor Kozel studies, were probably more common. Waln shows us the transition of Quakers from $18^{\text {th }}$ Century businessmen to the conscience of the nation by pressing American communities to live up to their stated values. Vanessa Julye's recent scholarship on Quakers and Slavery, Not Fit for Freedom, provides an excellent example of the complicated abolitionism within the Quaker community. This presence had two effects. First, it led to the evaporation of slavery in West Jersey. Second, it pressured all of the state's slave owners to defend their slave ownership at a very early date.

These effects that created this specific typology of slavery in New Jersey meant that its experience during the American Revolution engaged the tensions between slavery and freedom. The discussion over the boundaries of freedom had ensued before the Revolution and developed in, what seems to me to be, unique ways that the articles in this issue highlight. 
The research of Professor Kozel broadens the standard narrative of New Jersey's black soldiers and gives us a want for more. The overwhelming narrative in existing scholarship has focused upon the loyalist and renegade activity of a few black soldiers, like Colonel Tye, an ex-slave and officer for the British who recruited other blacks to raid Patriot households, mostly in Monmouth County. Kozel provides an intriguing example of a black Continental soldier: Peter Williams. Early in the war, New Jersey restricted the militia to whites but later opened it to allow masters to enlist their own slaves. Benjamin Quarles, the noted historian of the black experience during the American Revolution, cites two other whites who employed free blacks or slaves to replace them for their military service. But Williams did not achieve his freedom through service, but because his owner was Loyalist. New Jersey stripped his owner of his "property," and this freed Peter. His choice to serve was not a choice for personal freedom as it frequently was for slaves in the Continental army. Indeed, Peter Williams' experience led to his emancipation. ${ }^{3}$ Further research into the black military experience needs to give us insight into the diversity of experiences among these Continental army soldiers.

\footnotetext{
${ }^{3}$ Benjamin Quarles, The Negro in the American Revolution (Chapel Hill: University of North Carolina Press, 1996 reprint), pg. 59.
} 
Understanding slave loyalties in Revolutionary New Jersey is a difficult task. Traditionally, historians' narratives argue that Southern slaves revolted against their Patriot owners and fled to the British as a way to freedom and that the Northern Continental army invited slaves to join and often promised freedom for doing so. As pointed out before, the standard narrative of New Jersey emphasizes the loyalist behavior of slaves by making Colonel Tye the central black Revolutionary figure. This narrative of slave loyalty to Britain would seem to make sense, since New Jersey bordered British-occupied New York City. Many slaves, one would figure, seized the chance to flee to what they perceived to be a more-hospitable setting.

This familiar narrative line, however, appears to be wrong. Tim Hack shockingly demonstrates that slaves stayed on their plantations in order to maintain family structure. Jonathan Mercantini's work might shed even more light on the slaves' apparent loyalty to their owners. Perhaps the presence of Quakers and the early advent of paternalistic styles of slave ownership made the risky prospects of running away less attractive.

This should remind us of the momentous decision that lay before these slaves. Seeking freedom certainly had a deep meaning for 
enslaved men and women throughout the United States. However, the decision to run away was emotional and risky. Many slaves ran away; many more did not. Boston King, a South Carolina slave who decided to run to the British, explains this feeling vividly. Boston, exhausted by the "cruelty" of his enslavement, felt he had to escape. He described the risks of his decision as "throw[ing] myself into the hand of the English." He was, therefore, relieved when they "received me readily." He went on to explain that the "happiness of liberty" was tempered by the grief of losing his friends. ${ }^{4}$ Slaves in New Jersey had strong communal ties. New Jersey slaves saw a huge challenge and refused to jeopardize their family even for a short trip across the river.

A relatively large number of slaves chose to seek emancipation a safer way. They sought legal means to free themselves through the courts. Professor Kozel's research recognizes at least 30 of these cases in New Jersey and highlights three of them. These cases, known as freedom suits, or as Professor Kozel calls them, manumission cases, were widespread throughout the Revolutionary era. My own research on Massachusetts and South Carolina demonstrates this. In South Carolina, the most-oppressive slave regime in the United States, had

\footnotetext{
${ }^{4}$ See Boston King's essay in Face Zion Forward: First Writers of the Black Atlantic, 1785-1798, edited by Joanna Brooks and John Saillant (Boston: Northeastern University Press, 2002), pg. 212.
} 
three such cases despite tremendous obstacles. Massachusetts, with its relatively small slave population, had a few dozen, a couple of which toppled the institution of slavery in the state. ${ }^{5}$

As the research in this collection demonstrates, New Jersey's freedom suits run between these two extremes. The number of suits was similar to Massachusetts, however, their function was consistently more conservative than the most radical cases in Massachusetts. But in doing so, they demonstrate the interesting complexity of defining freedom during the Revolutionary era.

Professor Kozel recognizes three different parties involved in these cases. The Quaker advocates of the slaves, the slaves, and the legal system. The slaves were contesting their illegal enslavement. They did not demand to end slavery in New Jersey. They simply sought individual emancipation based upon illegal bondage. The slave certainly sought to gain the liberty that the Revolutionary era seemed to promise and questioned the institution of slavery, especially for himself or herself. Professor Kozel's research demonstrates that the Quaker advocates also used these cases to advance their cause to abolish

\footnotetext{
5 Blanck, Emily. "The Legal Emancipations of Leander and Caesar: Manumission and the Law in Revolutionary South Carolina and Massachusetts," Slavery and Abolition, August 2007, 235-254.
} 
slavery in the state in an incremental way. For the slaves and Quakers, Revolutionary ideas of freedom did include abolition.

For the courts, however, these cases do not give us any insight into the desire of the court to emancipate slaves wholesale. In fact, these cases could have reestablished a more-stable legal institution of slavery. For the post-colonial states, liberty was defined in terms of legitimacy. Each state labored at creating a legitimate state centered in republican principles. As the embryonic New Jersey state government hoped to create this legitimate and free state, it needed strong and legal institutions. To the New Jersey judiciary, the existence of illegally enslaved people undermined the integrity of the law. Therefore, new state governments opened up to emancipating at least some of their slaves, especially those who "deserved" it. The 30 or so cases that Professor Kozel presents fit into this vision of emancipation. For the New Jersey government, therefore, these cases represented a stronger, legal institution of slavery, not a movement toward abolition.

Virginia provides a similar example, and demonstrates how freedom suits reveal crucial aspects of Revolutionary legal culture. The post-Revolutionary era became an era of massive legal emancipation. Owners in Virginia freed thousands of their slaves. Almost all of the 
suits related to free parentage. Virginia's law clearly stated that a mother bestowed her status on her child. Some of Virginia's earliest laws and their basis of slave status in English common law on husbandry meant that this distinction of maternal birth was very significant. If a mother was a free American Indian, as many slaves were able to prove, the slave, according to a long history in the state, ought to be free. Likewise, Massachusetts valued contract and property law. Therefore, since the state recognized the slaves' right to own property and engage in a contract, the majority of freedom suits in Massachusetts sued on the basis of a broken contract. If an owner agreed to free a slave after certain conditions were established and did not or sold the slave in the midst of that contract, the courts supported the slaves. As scholars explore New Jersey emancipations, they should scrutinize the cases to understand how the suits reflect basic legal values of the state. ${ }^{6}$ Too often the history of the American Revolution is a history of men. We see in these papers hints of the roles women played. In Professor Mercantini's telling, Susan Kean, a white woman, used slavery as a tool for independence. As the mistress of the plantation, Mrs. Kean

\footnotetext{
${ }^{6}$ Michael L. Nicholls, "'the Squint of Freedom': African-American Freedom Suits in PostRevolutionary Virginia," Slavery and Abolition 20, no. 2 (1999); Eric Robert Papenfuse, "From Redcompense to Revolution: Mahoney V. Ashton and the Transfiguration of Maryland Culture, 17911802," Slavery and Abolition 15, no. 3 (1994); Christopher Phillips, "The Roots of Quasi-Freedom: Manumission and Term Slavery in Early National Baltimore," Southern Studies 4, no. 1 (1993).
} 
was a "savvy investor and entrepreneur" who had a good deal of control over household production and management. Moreover, in the accounts of both Professor Mercantini and Professor Kozel, female slaves gained emancipation. I urge New Jersey scholars to think about the gendered dimensions of these emancipations. In particular, Professor Mercantini highlights the female slave, Celia. She was possibly a victim of the sexual advances of Kean. As a nurse, she would have fairly intimate opportunities to interact with the family. He was protective of Celia as a pregnant woman, while at the same time he sought to keep her away from the New York-New Jersey areas, where his wife spent most of her time. Moreover, he chose to emancipate Celia and her son Caesar, whom Kean chose to be his personal servant. It was not uncommon for masters to feel especially protective of their children of slave women and to teach them skills that would help them gain freedom.

Likewise, Professor Hack's emphasis on the draw of family life adds a gendered element to the study of this period and region. Without a relatively even gender balance, this conservative impulse to stay on the plantation would not exist. This strong balance does not exist in most other slave states. Massachusetts, for instance, had an abundance 
of female slaves, while South Carolina had a dearth. South Carolinian

slave owners wished for "as many young Men as possible."

Massachusetts received the "refuse trade" - the leftover slaves from slave trading expeditions - who did not sell in the South because they were too young, female or appeared to be feeble. These demographics change the everyday life on the plantation and perhaps made the goals of the average slave in a Revolutionary era more conservative. ${ }^{7}$

This gender balance reminds us of the key reason why New Jersey deserves more attention. New Jersey is a liminal state. As the fulcrum of the balance between slave societies and societies with small populations of slaves, it gives us insight into the nature of that intermediate status. What we find is not that slavery is just in between what happened in New England and the South, but that it is uniquely New Jersey slavery on its own trajectory.

Likewise, the unique population of New Jersey meant that the Revolutionary Era created a Great Awakening. Professor Hack argues that the stability of family offered slaves the inspiration to delve into a religious life. Two slave-friendly religions made inroads into New

\footnotetext{
${ }^{7}$ Morgan, Slave Counterpoint: Black Culture in the Eighteenth Century Chesapeake \& Lowcountry (Chapel Hill: University of North Carolina Press, 1998), 70. Piersen, Black Yankees : The Development of an AfroAmerican Subculture in Eighteenth-Century New England 3-5.
} 
Jersey. The Methodists were not openly anti-slavery as they were in colonial and Revolutionary Virginia, but they enthusiastically opened their doors to people of all color and status. In contrast, the Quakers already had established themselves as an anti-slavery religion. As Professor Kozel shows, some Quakers took time to let go of their slave property and others did not see African American Friends in a totally egalitarian light, but compared to any other group in Revolutionary America, they provided the most radical environment toward erasing inequality. The existence of these friendly religious orders must have made an impact on slave ownership. Further research into black and white forms of religious culture in New Jersey should reveal a more complex story of the relationships between slaves, religion and abolitionism.

Moreover, this centeredness of New Jersey goes beyond these conceptual evaluations of slavery, but includes the actual centeredness in the lives of Revolutionary Americans. Its location meant that its population was highly transient. As recent scholarship in Atlantic World Studies has shown, Americans traveled outside of their own state, and New Jersey demonstrates this concept with its particularly porous borders. Professor Mercantini's research into the Kean family 
demonstrates how many wealthy Americans lived in two states. A few scholars have noted the relationship between Rhode Island and Southern Plantation owners, but the Kean family reminds us that this relationship was not exclusive to Newport, where the major slavetrading families lived. Likewise, Professor Kozel's work shows us how insignificantly the Delaware River affected relationships between Pennsylvania and New Jersey. The Quaker activist Waln was born in Philadelphia, lived in New Jersey, and was active in the anti-slavery cause on both sides of the Delaware.

However, for some, the Hudson River was much harder to cross. For a slave, the Hudson was a permanent border. Professor Hack's conclusions suggest that the slaves did not leave New Jersey for New York because that decision would mean a loss of community and/or family. Undoubtedly, further research into relationships between New York and Delaware and the neighboring New Jersey residents will show similar porousness. All of this mobility was enhanced even more deeply with the alliances and movement during the Revolution.

This centrality of New Jersey as a border state would extend throughout the antebellum era. It was a fractured state, filled with some who felt dependent on slavery and those vociferously opposed to it. As 
such, it took longer for New Jersey to end slavery than any other Northern state. Symbolically, Salem, Cumberland, Cape May and parts of Gloucester and Ocean counties were Southern in outlook. Even today, a Civil War reenacting group in New Jersey identifies itself with Robert E. Lee rather than any of the great Union generals. ${ }^{8}$

New Jersey during the American Revolution offers a unique and enlightening study to understand the boundaries of freedom and slavery as the nation was trying to define these ideas. Furthermore, by studying at New Jersey, we remember that state boundaries were fluid. Pennsylvania and New Jersey Quakers worked together. Slaveowners like Kean could live in the world of New Jersey and South Carolina, and slavery could expand in the North, turning our basic understandings of slavery in Revolutionary America on its head.

\footnotetext{
8 "The Robert E. Lee Roundtable of Central Jersey," http:/ / www.roberteleecwrt.com/ accessed
} on 20 June 2010. 